Gi respons på artikler gjennom artiklenes kommentarfelt på tidsskriftet.no. Innleggene publiseres fortløpende på Tidsskriftets nettside og et utvalg

\section{Re: Kronisk utmattelsessyndrom/myalgisk encefalopati - sykdomsmekanismer, diagnostikk og behandling}

Fra to artikler i Tidsskriftet $(1,2)$ kan det virke som om de vitenskapelige kontroversene rundt kronisk utmattelsessyndrom/myalgisk encefalopati (CFS/ME) skyldes mangelfulle kriteriesett og utilstrekkelige data. Men dette er bare delvis riktig, og da hovedsakelig i avledet forstand. Dette fordi elefanten i rommet er mangelen på teoretisk forståelse av hva $\mathrm{CFS} / \mathrm{ME}$ er. Derfor lar kontroversene seg vanskelig løse, og dermed står forskerkollektivet overfor en tilsvarende situasjon som den dommer Potter Stewart sto overfor da han i 1964 skulle identifisere pornografiske handlinger. Hva pornografi er, kunne han ikke si, men han var likevel overbevist om at «I know it when I see it» (3).

Vegard Bruun Wyller og medarbeidere, som lenge har sett elefanten i rommet (2), har lansert en teori som søker å sammenfatte data i en enhetlig forklaringsmodell. CFS/ME beskrives som et resultat av predisponerende (gener, personlighet) og utløsende (infeksjoner, kritiske livshendelser) faktorer, og modellen evner med det å ta opp i seg immunologiske så vel som nevrologiske og endokrine aberrasjoner. Sentralt i modellen er det dessuten at mennesket evolusjonært sett er adaptert til å takle de utløsende faktorer, men at individer som utvikler CFS/ME utvikler en patologisk «vedvarende stressrespons».

Jeg har tidligere lansert en samsvarende modell $(4,5)$, men har lagt vekt på at enkeltmenneskets adaptive potensial er vel så mye ontogenetisk som fylogenetisk ervervet. Hendelser i tidlige barneog ungdomsår setter spor i den utviklende organismens adaptive organer - inklusive de immunologiske, endokrine og sentralnervøse. Og disse sporene bidrar i sin tur til at hver enkelt utvikler ulike adaptive grenser. Kjennskap til hvilke typer hendelser tidlig i livet som disponerer for utvikling av enkeltindividets triggergrenser og dermed for en «vedvarende stressrespons», vil derfor være av betydning for forståelsen av CFS/ME.

Gitt en slik modell blir det forståelig at B-celledeplesjon (6) og kognitiv terapi (2) begge vil kunne fungere som terapi for noen, men ikke for alle - begge behandlingene gir effekter ved at de reformaterer kroppens ontogenetisk deriverte adaptive grenser.

\section{Elling Ulvestad}

elling.ulvestad@helse-bergen.no

Elling Ulvestad (f. 1958) er avdelingssjef og professor ved mikrobiologisk avdeling, klinisk institutt, Haukeland universitetssykehus.

Ingen oppgitte interessekonflikter.

\section{Litteratur}

1. Egeland T, Angelsen A, Haug R et al. Hva er egentlig myalgisk encefalopati? Tidsskr Nor Legeforen 2015; 135: 1756-9

2. Wyller VB, Reme SE, Mollnes TE. Kronisk utmattelsessyndrom/myalgisk encefalopati - sykdomsmekanismer, diagnostikk og behandling. Tidsskr Nor Legeforen 2015; 135: 2172-5.

3. Wikipedia. I know it when I see it. https://en.wikipedia.org/wiki/ I know_it_when_l_see_it (7.12.2015).

4. Ulvestad $\bar{E}$. Chronic fatigue syndrome defies the mind-body-schism of medicine. New perspectives on a multiple realisable developmental systems disorder. Med Health Care Philos 2008; 11: 285-92.

5. Ulvestad E. Psychoneuroimmunology: the experiential dimension. Methods Mol Biol 2012; 934: 21-37

6. Fluge $\emptyset$. Bruland O, Risa K et al. Benefit from B-lymphocyte depletion using the anti-CD20 antibody rituximab in chronic fatigue syndrome. A double-blind and placebo-controlled study. PLoS One 2011; 6: e26358.

\section{Re: Kumulert sum ved overvåking av postoperative sårinfeksjoner}

Vi har med interesse lest innlegget til Brustad \& Walberg i Tidsskriftet nr. 20/2015 om lokal bruk av rapporter fra Norsk overvåkingssystem for antibiotikabruk og helsetjenesteassosierte infeksjoner (NOIS) og andre alternativer (1). Rapporter som tilbys i NOISnett, skal være lette å tolke og gi beslutningstøtte til ledelse, kirurger og smittevernpersonell. Formålet med NOIS er bl.a. å oppdage og bidra til oppklaring av utbrudd eller endring i insidens av helsetjenesteassosierte infeksjoner og gi datagrunnlag for å evaluere tiltak. Rapporter som viser forekomst av infeksjoner i operasjonsområdet i egen institusjon sammenlignet med andre med tilsvarende pasientpopulasjon samt antall operasjoner mellom slike infeksjoner, kan belyse disse forholdene og ble prioritert da vi utviklet NOISnett. Ytterligere rapporter vil bli utviklet for kommende versjoner av NOISnett, og disse vil også kunne dra nytte av at NOIS fra 2013 inneholder helårsdata.

Brustad \& Walberg viser til et eksempel fra Vestre Viken, hvor de har brukt kumulert sum for å kunne følge tidsutviklingen, og mener dette er en enklere måte å visualisere data uten statistisk støy. Dette er dessverre ikke helt uproblematisk, og det konkrete eksemplet er etter vår mening ikke lett å tolke. Figuren viser tilsynelatende en endring i perioden mai 2012 til mai 2014, men det kommer ikke frem at denne endringen kan være et artefakt som kan tilskrives datatilgang, ikke en reell endring i infeksjonsforekomst. Videre brukes som referanse et nasjonalt gjennomsnitt som ikke tar hensyn til ulikheter i pasientpopulasjon. Figuren er trolig basert på flytende gjennomsnitt og viser langsiktige endringer over tid. De er mindre sensitive overfor nylige endringer. Det kan derfor stilles spørsmål ved om denne figuren bidrar vesentlig som beslutningstøtte for ledelse, kirurger og smittevernpersonell. Brustad \& Walberg refererer til metoden kumulert sum, men det er ikke tilstrekkelig med forklarende tekst til figuren til å kunne tolke bruken av metoden.

Det er ikke enkelt å presentere overvåkingsdata som tilfredsstiller alle behov, men siden et av formålene med NOIS-overvåkingen nettopp er lokal bruk av data og utvikling av egne rapporter, setter vi stor pris på tilbakemeldinger og innspill som kan bidra til utvikling av det nasjonale systemet. Vestre Viken har gitt oss flere gode eksempler på viktigheten av å bruke NOIS-data lokalt for å bedre pasientsikkerheten. NOISnett har per dags dato begrensninger, men det jobbes kontinuerlig med å forbedre mulighetene for uthenting av rapporter.

Vi ønsker å understreke at alt helsepersonell kan få tilgang til rapporter i NOISnett og oppfordrer alle, inkludert ledelsen, til å gå inn i NOISnett og bruke egne data aktivt i forbedringsarbeid, slik det gjøres i Vestre Viken.

\section{Jørgen Bjørnholt \\ jorgen.bjornholt@fhi.no Oliver Kacelnik \\ Hanne-Merete Eriksen}

Jørgen Bjørnholt (f. 1962) er overlege ved Folkehelseinstituttet. Ingen oppgitte interessekonflikter.

Oliver Kacelnik (f. 1977) er lege ved Folkehelseinstituttet.

Ingen oppgitte interessekonflikter. 